\title{
A vertikális migráció szerepe a hazai szénhidrogén-felhalmozódások feltöltődésében
}

\author{
KonCZ István
}

koncz.istvan38@chello.hu

\section{The role of vertical migration in the charge of known hydrocarbon fields, Hungary}

\begin{abstract}
By giving a general overview of hydrocarbon charge, with special focus on vertical migration, the author of this study attempts to evaluate the relationship between the hydrocarbons generated in deeper areas of a basin and accumulated in shallower parts. The selected examples - according to the available geochemical data - confirm the vertical charge of the known fields. This shows hydrocarbons along the fault zones connecting the shallower reservoirs with the effective source rocks located at the deeper parts of the basin.
\end{abstract}

Keywords: hydrocarbons, vertical migration, Hungary

Összefoglalás

A szerző áttekintést ad a tárolók szénhidrogénekkel való feltöltődését eredményező migrációról, különös tekintettel a vertikális migrációra. Megkísérli a mélyebben képződött és a medence sekély részein felhalmozódott szénhidrogének közötti kapcsolat értékelését. A kiválasztott példák — a hozzáférhető geokémiai adatok szerint — megerôsítik az ismert mezők szénhidrogénekkel történt vertikális feltöltődését olyan vetőzónák mentén, amelyek összekötik a sekélyebben fekvő tárolókat a medence mélyebb részein elhelyezkedő effektív anyakőzetekkel.

Tárgyszavak: szénhidrogének, vertikális migráció, Magyarország

\section{Bevezetés}

A migráció a szakirodalom szerint a kőolaj és a földgáz mozgását jelenti a felszín alatti kôzetekben. Ez a kifejezés abban az időszakban keletkezett, amikor felismerték, hogy a kőolaj és a földgáz nem ott képez felhalmozódásokat, telepeket, ahol létrejött: a kőolajnak és a földgáznak képződési helyéről, a kőolaj és a földgáz tárolására igen kevéssé alkalmas, tárolótérrel alig rendelkező ún. anyakőzetből el kell távoznia, migrálnia, hogy a szerkezetekben felhalmozódásokat, telepeket képezhessen. A felismerés előzménye az, hogy bizonyítottá és általánosan elfogadottá vált a kőolaj és a földgáz szerves eredete. Az üledékes kôzetek szerves anyaga koncentrációjának mértékéül szolgáló szerves széntartalom (TOC - total organic carbon) a telepeket magában foglaló kőzetekben, a tárolókőzetekben igen csekélynek bizonyult, viszont azok a finomszemcsés üledékes kőzetek, a pelitek, amelyek tárolótér hiányában nem tartalmaztak felhalmozódásokat, jelentősen nagy szerves széntartalommal rendelkeztek (HUNT \& JAMIESON 1956, RoNOv 1958). A szerves anyag mennyisége mellett a minősége is mérvadó lehet, amelyet a Rock-Eval-analízisek eredményei között szereplő hidrogénindex jellemez, ha a szerves anyag átalakultsága még kismérvú. Nyilvánvaló, hogy érdemi mennyiségú kőolaj és földgáz ennél fogva a pelitekben képződhet, ha a pelitek az üledékképződés folyamán mélyebbre, magasabb hőmérsékletre kerülnek. Ezek a pelitek, illetve a jelentősen nagy szerves széntartalommal rendelkező kőzetek az ún. anyakőzetek. Az anyakőzetekben képződött szénhidrogének az ún. primer migráció során távoznak az anyakőzetekkel közvetlenül érintkezô durvaszemcsés, tárolótípusú kőzetekbe, amelyek 
migrációs vezetôszinteknek tekinthetôk. A durvaszemcsés kôzetbe jutott kőolaj és földgáz az ún. szekunder migráció során kerül el a szerkezeti magaslatokhoz és/vagy a sztratigráfiai csapdákba, ahol felhalmozódásokat képez. A szénhidrogének kőzetekben való mozgását ez esetben rétegmenti (laterális) migrációnak kell tekinteni. Az előzőokben leírt migrációs folyamatokat az 1 . ábra A része szemlélteti. A szekunder migráció szállítóközege a víz, hajtóereje a földgáz és a víz, valamint a kőolaj és a víz sứrúségkülönbségéből adódik. Emellett a kőzet áteresztôképessége, a nyomásgradiens, a kőolaj és földgáz viszkozitása, valamint a kapilláris nyomás is meghatározó eleme a fluidumok mozgásképességének. A kőzet áteresztôképessége, a nyomásgradiens, a kőolaj és a földgáz viszkozitása az áramlást leíró Darcy-törvénnyel kapcsolatos, amely meghatározza

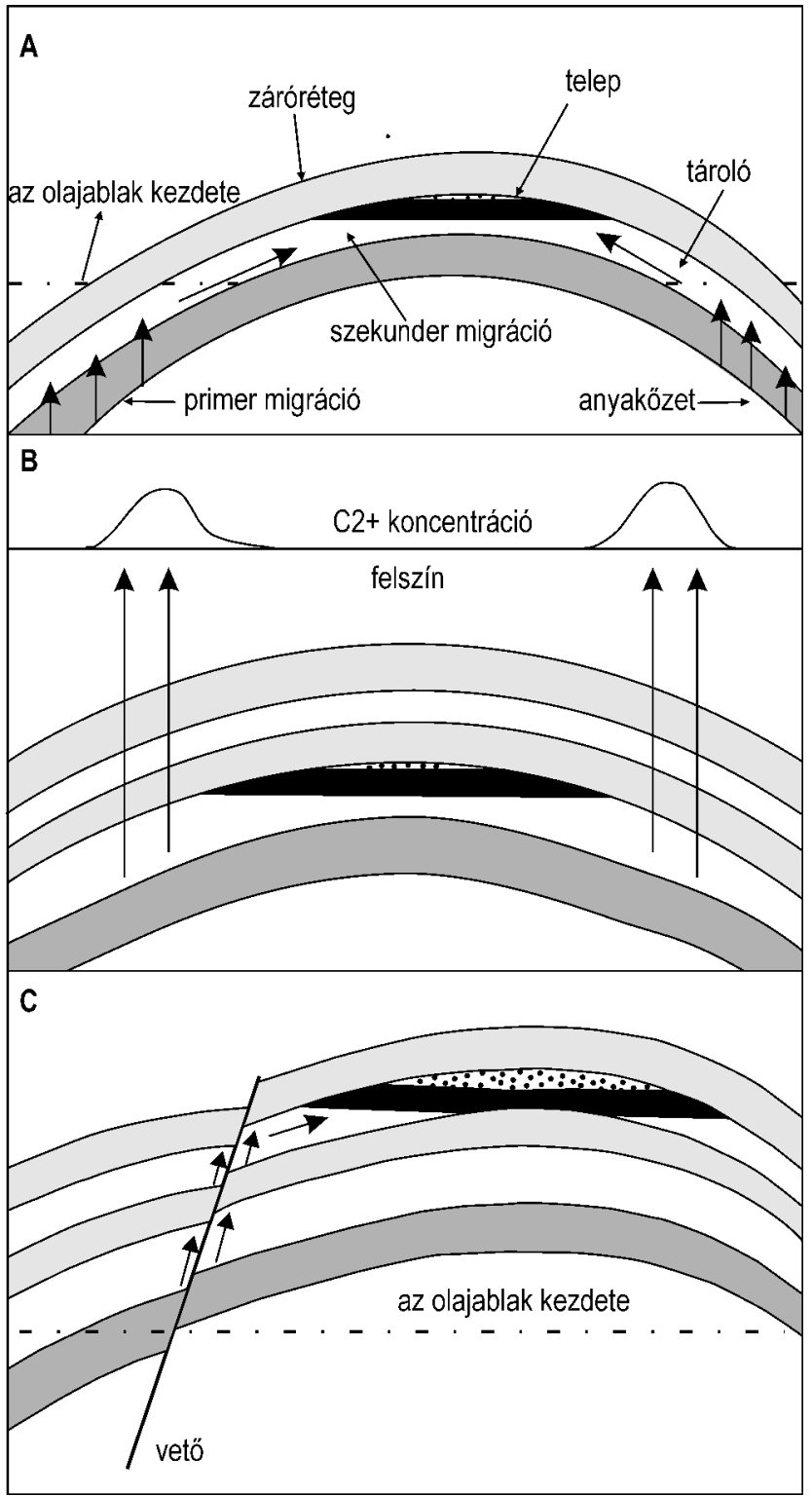

1. ábra. A migráció típusai: A - rétegmenti (laterális), B - vertikális, vetők nélkül, $\mathrm{C}$ - vertikális, vetőkkel

Figure 1. Migration types: $A$ - lateral, $B$-vertical without faults, $C$-vertical with faults azt, hogy időegység alatt mekkora térfogatú fluidum képes áthaladni egységnyi kôzetfelületen. A sứűségkülönbségekből adódó felhajtóerô ellenében múködik a kapilláris nyomás, ami ahhoz szükséges, hogy a kőzet pórusait összekötő szúkületeken átjuttassa az olajcseppeket, illetve gázbuborékokat. A kapilláris nyomás az olaj és víz, valamint a gáz és víz közötti határfelületi feszültségtôl, továbbá a pórusok méreteitől függ. Az előzőekben említettek írják le a szekunder migráció folyamatait (HOBSON 1954). A kőolajjal ellentétben, amely a víztól elkülönüló fázist alkot, a földgáz és a benne lévő szénhidrogéngázok jelentős része vízben oldódik, így egyfázisú rendszert is képezhet. A felhalmozódott földgáz és kőolaj felszín felé, a nyomáscsökkenés irányában történő „elszökését” a tárolókôzetet fedő, pelitekből álló záróréteg akadályozza meg. A záró-, illetve fedôréteg pórusméretei sokkal kisebbek, mint a tárolókôzetekéi, ezért a fedőréteg kapilláris nyomása elegendóen nagy ahhoz, hogy az olajcseppek és a gázbuborékok mozgását a fedôrétegen keresztül megakadályozza. A víz a benne oldott gázokkal együtt egy bizonyos mélységhatárig képes ,átszivárogni” a zárórétegen. A kôolaj-, illetve földgáz-felhalmozódással érintkezô víztestből a zárórétegen, illetve a zárórétegeken át a vízben oldott szénhidrogéngáz komponenseket tartalmazó rendszer képes áthatolni, sốt a felszínig jutni (1. ábra, B). Ez a rétegeket átmetszó, azaz vertikális migráció képezi az alapját a felszíni geokémiai módszerek egyikének, amely a talajon adszorbeált etán és annál nagyobb szénatomszámú gázkomponensek koncentrációjának anomálisan nagy értékei révén képes jelezni a telepeket bizonyos mélységhatárig (STAHL et al. 1981). A metán koncentrációja erre azért nem alkalmas, mert a metán lehet teljes egészében vagy részben bakteriális eredetú, amely az anyakőzetek szerves anyagának hôbomlásából keletkezett, termogén eredetú szénhidrogéneket (etánt, propánt is) tartalmazó felhalmozódásoktól függetlenül jelen van a sekélyebben fekvő rétegek vizében. Ebből az is következik, hogy a vízben oldott állapotú, bakteriális eredetú metán vertikális migrációja révén megnöveli a sekélyebben lévô képződmények vizében a metánkoncentrációt. Ha a metán koncentrációja a vízben eléri, illetve meghaladja az adott viszonyok között a metán vízben való oldhatóságát, akkor gázfázis jön létre. Az ily módon kialakult kétfázisú rendszer szabad gáza azonban már nem képes a peliteken átszivárogni, és a felszín felé tovább migrálni. Az itt részletezett folyamat, a vertikális migráció révén is kialakulhattak a bakteriális metánt tartalmazó földgáztelepek, ha a rétegvizek bakteriális metántartalma eleve alacsony volt, és így telepet más módon nem hozhatott létre. Az a kérdés még megválaszolatlan maradt, hogy az anyakőzetekből miképpen tud távozni a primer migráció során a kőolaj és a földgáz. A primer migráció hajtóereje - a mozgást akadályozó kapilláris nyomáskülönbség ellenében - a tároló típusú kôzetek, a homokkövek és a velük közvetlenül érintkezô anyakốzetek, a pelitek közötti nyomáskülönbség: a pelitekben egy kissé nagyobb a nyomás, mint a velük közvetlenül érintkező homokkövekben (SZALAY \& KonCZ 1980). Ennek oka az, hogy a homokkövek és a pelitek eltérő ütemben tömörödnek (kom- 
paktálódnak), amikor az üledékképződés során egyre mélyebbre kerülnek, és a felettük lévő kôzetekből adódó nyomásterhelés növekszik. A Délkelet-Alföld fúrásaiból származó homokkövek a 10\% porozitást 3000 m mélységben érik el, a pelitek viszont már $2000 \mathrm{~m}$ mélységben, továbbá a pelitek $3000 \mathrm{~m}$ mélységben $0,1 \mathrm{mD}$ (millidarcy, $10^{-16} \mathrm{~m}^{2}$ ) nagyságrendú áteresztôképességgel rendelkeznek, a homokkövek ezt a nagyságrendet $5000 \mathrm{~m}$ mélységben érik el (SZALAY 1982). A pelitek hézagtere és fluidumátbocsátó képessége (áteresztôképessége) gyorsabban csökken, mint a homokköveké, ami azt eredményezi, hogy a pelitekből a víz kiszorulása gátolttá válik: bennük a nyomás így egyre inkább nagyobb lesz, mint a homokkövekben, és a pelitekből a nyomáskülönbség hatására a fluidumok a pelitekkel érintkező homokkövek irányában mozognak a kapilláris nyomás ellenében, ami a pelitekben nagyobb mértékben gátolja az olajcseppek és a gázbuborékok mozgását. Ez a primer migráció hajtóerejeként múködő differenciális kompakció azzal jár, hogy az anyakőzetekből jelentős mennyiségû víz jut az anyakôzetekkel közvetlenül érintkező homokkövekbe, mint szekunder migrációs vezetőszintekbe. Hazai viszonyok között a neogén anyakőzetek vizével együtt, oldott állapotban képes távozni a bakteriális eredetú gáz. A kompakciós eredetú víz jelenlétében végbemenő primer migráció a kőolaj esetében igen ritka: csak abban az esetben megy végbe, ha az alacsony érettségú szerves anyagot tartalmazó anyakőzet az átlagosnál jóval kedvezőbb, kitúnô tulajdonságokkal rendelkezik. A víz kiszorulása a neogén anyakőzeteinkbőll 1900 m mélységig mehet végbe, mert 1900 m-nél nagyobb mélységben a pelitek áteresztôképessége oly mértékben kicsiny, hogy csak az igen lassú „szivárgást” teszi lehetôvé (Szalay \& Koncz 1980). A pelitekből történő nagymérvú szénhidrogén-eltávozás éppen ezért a pelitek felrepedéséhez köthető, amikor a túlnyomás mértéke eléri a vertikális irányú fedőkőzet-terheléssel összefüggő horizontális vagy laterális irányú feszültség és a húzószilárdság összegét (ROUCHET 1981). Neogén mélymedencéinkben az olajablak kezdete, ahol az érdemi szénhidrogén-képződés az átlagos tulajdonságokkal rendelkező neogén korú anyakőzetekben megindul, minimálisan 2400 méter mélységre tehetô. Tehát, az átlagos tulajdonságokkal rendelkező anyakőzzetek esetében a szerves anyag hőbomlása eredményeként képződő kőolajnak és termogén gáznak kevés az esélye arra, hogy az anyakőzetek kompakciója során kiszoruló vízzel távozzék.

$\mathrm{Az}$ üledékképződés további menete során az anyakôzetekből, pelitekből nem távozik érdemi mennyiségú víz, főleg akkor nem, ha az üledékképződés olyan nagy ütemú, mint a pannóniai időszak alatt az üledékes medencéinkben: a pelitekből igen lassan szivárgó víz nem tud „lépést tartani” a gyors üledékképződés miatt megnövekvő fedőkőzet-terhelésből adódó nyomásnövekedéssel. A pelitek így tovább alig tömörödnek, alulkompaktáltakká válnak, továbbá a fedőkôzet vastagságának növekedésébőll származó nyomásnövekedés a pelitek hézagterében lévő víz nyomását növeli meg: a pelit túlnyomásossá válik, a hézagtér fluiduma áramlási szempontból egyre izoláltabbá lesz. (Persze, a homok- kövekben is megjelenik a túlnyomás, csak kisebb mérvú, mint a vele érintkező pelitekben.) Említésre méltó, hogy a pelitréteg homokkővel érintkező alsó és felsổ része a távozó rétegvíz miatt nagyobb mértékben tömörödik, kompaktabbá válik, ezáltal — gátat képezve — korlátozza a víz további mozgását a pelitréteggel érintkező, nagyobb áteresztőképességú homokkövek irányában. Ebből következik, hogy a pelitréteg alsó és felsô részéből a képződött szénhidrogének a vízzel együtt még el tudnak távozni. A tagolatlan, vastag pelitek esetében a pelit teljes térfogatához viszonyítva a kompaktálódó felső és alsó rész kicsiny. A vékony, tagolt pelitekből így viszonylag több szénhidrogén képes távozni: primer migrációs hatásfokuk nagyobb, mint a vastag, tagolatlan peliteké (BROOKS et al. 1987). Az előzóekben részletezett folyamatnak tulajdonítható, hogy a Pannon-medence alföldi részén 2500 m-nél nagyobb mélységben már csak túlnyomásos képződmények vannak (SZALAY 1982). Izolált körülmények között a primer migráció erősen gátolt, magának a primer migráció folyamatának a megértése sok nehézségbe ütközött és ütközik (DURAND 1988). Ha a pelitek hézagterében lévô fluidum nyomása eléri a fedőkőzet-vastagságnak megfelelő ún. litosztatikus nyomásnak a pelitek Poisson-aránya által megszabott hányadát, akkor az anyakőzet felrepedezik (microfracturing) (PAYNE et al. 2000, CosGrove 2001). A felrepedés következtében a hézagtér fluidumának nagy része távozik, miközben az anyakőzet térfogata a felrepedés és fluidum-kiáramlás miatt csökken. A térfogatcsökkenés eredményeként vetôk keletkezhetnek, amelyek mint vertikális migrációs csatornák továbbíthatják a szénhidrogéneket a jóval kisebb mélységben elhelyezkedô tárolókba. A felrepedés és fluidum-kiáramlás után az anyakőzet a fedőkőzet-terhelés miatt záródik (healing), és zárva marad a következő felrepedésig, ha az üledékképző́dés folytatódása miatt nagyobb mélységbe kerül. Az újólagos felrepedés során az előzőnél érettebb szénhidrogének távoznak. Említésre méltó, hogy a túlnyomást növeli a víz hőtágulásából és a szénhidrogén-képződésből adódó nyomástöbblet (HuNT 1990). A túlnyomás által létrejött felrepedés és fluidum-kiáramlás a kompakciós eredetú migrációs folyamattal ellentétben független az anyakőzet tulajdonságaitól: a szerves anyagban szegényebb anyakőzetekből is távoznak szénhidrogének (KoNCZ 2018a). Mind a kompakciós, mind a túlnyomás által okozott felrepedés következtében végbemenő primer migráció alacsony hatásfokú: a képződött szénhidrogének jelentős hányada az anyakőzzetben marad, ami a szerkezetekben felhalmozódott, ún. hagyományos készleteknél nagyságrendileg nagyobb, és az ún. nem hagyományos készletek forrását képezi. Ide tartozóan célszerú megemlíteni, hogy az ún. tömör homokkövek (,tight sandstone”) esetében a pórusok közötti szúkületek (pórustorkok) mérete kisebb, mint $2 \mu \mathrm{m}$ (NELSON 2009). Ilyen körülmények között csak egy fázis, a gáz áramlása lehetséges 50\%-nál nagyobb gáztelítettség esetén, két fázis, a gáz és a víz áramlása nem lehetséges (SHANLEY et al. 2004).

A túlnyomás által megrepesztett pelitekből történő primer migráció során a vetőkön keresztül vertikálisan 
migrálva a szénhidrogének a sekélyebben fekvő tárolókig is eljuthatnak, amelynek környezetében a szerves anyag még alig alakult át (termikusan alacsony érettségú), vagy átalakulatlan (termikusan éretlen) (1. ábra, C). Meg kell jegyezni, hogy a földgáz és a kőolaj vetôkön, töréseken át végbemenő vertikális migrációja nagyságrendekkel gyorsabb folyamat, mint a vízfázisban oldott szénhidrogéngázok szivárgása a zárórétegeken keresztül. A vetôk csak függóleges metszetben mutatnak vonalszerú alakzatot, a térben viszont felületet, egyszerúbb esetben vetôsíkot képeznek. A vetôsík bizonyos feltételek esetén tud úgy viselkedni, mint egy nyitott törés. Például, ha kis mélységben van, vagy ha igen nagy a túlnyomás, végül akkor, amikor a vetô éppen létrejön vagy felújul (DownEY 1994). A vetőkkel kapcsolatos megfontolások jelentôs része azzal függ össze, hogy egy olyan szerkezetben, amely szénhidrogén-akkumulációt tartalmaz, és egyik záróelemét vetố alkotja, megmarad-e a felhalmozódás, vagy a vetôn keresztül a kisebb mélységben lévő tárolóba, a legrosszabb esetben a felszínre kerülnek a szénhidrogének. A tárolókőzettel érintkező, azt térbelileg lehatároló vető felülete akkor zár, ha a vetô felületét képezô kôzet kapilláris nyomása nagyobb, mint az olajcseppekre, illetve gázbuborékokra ható felhajtóerô (SORKHABI \& Tsuji 2005). Ha a vető vagy törés eléri a felszínt, olajfolyás, illetve gázkifúvás jön létre. A felszíni szeizmikus módszerek elterjedését megelőző időszakban a felszíni olajfolyások és gázkifúvások jelentették az egyedüli támpontot a siker reményében mélyítendő fúrások számára. A vetôk szerepére hívta fel a figyelmet PRICE (1980). A szerző bőségesen sorolt fel a világ minden részérôl példákat a vetőkön keresztül végbe mehetett vertikális migrációra, amelynek folyamán a mély medencékben képződött szénhidrogének a sekélyebben elhelyezkedő tárolókban halmozódhattak fel. Geokémiai adatokkal azonban nem támasztotta alá feltevéseit. Ezen cikk szerzője megkísérli, hogy geokémiai adatokkal valószínúsítse a magyarországi neogén tárolók szénhidrogénjeinek migrációs kapcsolatát a mélyebben fekvő és idősebb anyakőzetek szénhidrogénjeivel. Alapvetően az alábbi három eset, illetve azok kombinációi fordultak elő:

a) a sekélyebben fekvő tárolók szénhidrogénjei jóval érettebbek, mint a mélyebben fekvőkéi,

b) genetikai korrelációkkal bizonyítottan a sekélyebben fekvő tárolók szénhidrogénjei a nagyobb mélységben lévő idősebb anyakőzetekből származnak,

c) a sekélyebben fekvő tárolók környezetében lévő szerves anyag érettsége jóval alacsonyabb, mint a tárolókban felhalmozódott szénhidrogéneké.

PRICE felvetése nem talált lelkes fogadtatásra, mert a geológusok többsége a rétegmenti (laterális) migráció híve maradt, és eleve szkeptikusan tekintett a vertikális migrációra (DEMAISON \& HuIZINGA 1994). Pedig a vetők és törések képesek nagy olajmezôt létrehozni, továbbá a vertikális migráció során sokkal kevesebb szénhidrogén ,,veszik el”, mint a rétegmenti, szekunder migráció folyamán (feltéve, hogy a vetők nem húzódnak a felszínig). Számítások szerint jelentős tömegú szénhidrogén képes a vetôsík felülete mentén átáramolni viszonylag rövid idő alatt (DowNEY 1984).

\section{A különböző anyagfajták termikus érettségének jellemzésére használt paraméterek}

\section{Az üledékes kózetek szerves anyagának érettsége}

Általánosan alkalmazott az üledékes kőzetek szerves anyaga termikus érettségének jellemzésére a vitrinitreflexió. Meg kell azonban jegyezni, hogy a vitrinitreflexió csak hozzávetôlegesen jelöli ki a szénhidrogénzónákat, például az olajképződés kezdetét. Ugyanis a vitrinitreflexió változását leíró kinetikai modellek nem közvetlenül az anyakőzetben lévő szerves anyag átalakulásának mértékét adják meg. Az anyakőzetek szerves anyagának átalakulásának mértékét az átalakulási tényezô adja meg pontosabban, amelyet az anyakőzet szerves anyagához rendelhető kinetikai modell segítségével számolunk. A vitrinit a devon kortól kezdődően lehet jelen az üledékes kőzetek szerves anyagában, mert a magasabb rendú szárazföldi növényzetből származik. A vitrinitreflexió a mikroszkóppal azonosítható vitrtinitszemcse fényvisszaverő képességét kifejező százalékérték. Lehetôség szerint 20-100 vitrinitszemcse reflexiójának átlagát adják meg vitrinitreflexió értékként (BosTiCK 1979). A kutatógeológusok körében elterjedt az ún. „olajablak” kifejezés, amely szerint a kőolajképződés a 0,6-1,3\% vitrinitreflexió tartományhoz köthetô. Az olajablak kezdetének megfelelő vitrinitreflexió azonban függ a szerves anyag (kerogén) típusától. A vitrinitreflexió 0,6\% értéke fooleg a III típusú (főleg gázt képző) kerogénre érvényes. Az olajképzô II (fôleg a IIS) típusú kerogén esetében 0,6\%-nál alacsonyabb, az I típusú, szintén olajképző kerogén 0,6\%-nál magasabb vitrinitreflexió értékek elérésekor kezd olajat generálni.

Magyarországon a mély, nem invertálódott neogén medencékben, ahol a folyamatos üledékképződés miatt minden képződmény jelenleg a valaha elért legnagyobb mélységben van, az ,olajablak” kezdete 2400-3000 m mélységintervallumú. A pannóniai üledékképzôdéshez rendelt delta- és alluviális síksági képződmények (az Újfalui és Zagyvai Formációk) szerves anyaga termikusan éretlen. Az olajablak kezdete zömmel a pannóniai üledékképződéshez tartozó mélyvízi turbidit és selflejtő képződményekben, a Szolnoki és Algyői Formációkban van. Tehát, ha a delta képződményeiben lévô tárolókőzetek olajat tartalmaznak, akkor az olajnak eleve vertikális migráció révén kellett felhalmozódnia. Noha a kinetikai modell szerint a termikus átalakulást mind a hômérséklet, mind az idô együttesen határozzák meg, a hômérséklet hatása az átalakulásra jóval nagyobb, mint az időé: az átalakulás mértéke exponenciálisan nô a hőmérséklettel és lineárisan az idővel. A kőolajképzôdés kezdete magasabb hômérsékleten van a Pannon-medence neogén képződményeiben (SzALAY \& KonCZ 1980). Ez a jelenség a hőmérséklet és az idő együttes hatását tükrözi (CONNAN 1974). 


\section{A kózetextraktumok és az olajok nehéz részének termikus érettsége}

Az üledékes kőzetek szerves anyagának hőbomlása, a katagenezis azzal jár, hogy az elágazó szénláncú ún. izoalkánoknál jóval nagyobbá válik a normál alkánok koncentrációja (Tissot \& Welte 1984). A gázkromatogramok alapján számított nC17/P és nC18/F arányok, azaz a 17 szénatomszámú normál alkán $(\mathrm{nC} 17)$ és a prisztán $(\mathrm{P})$, valamint a 18 szénatomszámú normál alkán (nC18) és a fitán (F) aránya a termikus érettség növekedésével nő. (A prisztán 19, a fitán 20 szénatomszámú izoalkán.) A prisztánfitán arány hatásának mérséklése céljából az nC17/P és az nC18/F arányok átlagát, a normál-izoalkán arányt (N/I) volt célszerü felhasználni a termikus érettség becslésére. Az N/I arány azonban nemcsak az érettségtől, hanem a szerves anyag (kerogén) minőségétôl, típusától is függ: olajgeneráló típusú kerogén esetében ugyanazon feltételek mellett az N/I arány nagyobb. Az N/I arány nem állapítható meg gázkondenzátumok esetében az N/I arányban szereplő szénhidrogének alacsony koncentrációi miatt. Gyakran előfordul, hogy az említett komponensek nem is jelentkeznek a gázkromatogramokon. Továbbá az ún. biodegradált olajoknál sem értékelhetô az N/I arány, hiszen a bakteriális múködés során először a normál alkánok kerülnek ,elfogyasztásra”.

A kőzetextraktumokat illetôen 940 N/I adat került értékelésre a középső-miocén-pannóniai korú anyakőzetekből. Meg kell említeni, hogy a kőzetextraktumok autochton helyzetet képviselnek: szénhidrogénjeik ott vannak, ahol képződtek. Az N/I értékek különböző mélység-intervallumokban eltérô eloszlást mutatnak (I. táblázat). Az alacsony $(\mathrm{N} / \mathrm{I}<1)$ értékek, amelyek termikusan éretlen állapotot képviselnek, a mélység növekedésével csökkenő részarányúak: 0-2000 m között 38\% az alacsony értékek hányada, 3000 m-nél nagyobb mélységben csak 7\%. A magas ( $\mathrm{N} / \mathrm{I} \geq 2)$, termikusan érett fokozatra utaló értékek részaránya 0-2000 m intervallumban csak 13\%, 3000 m-nél nagyobb mélységben 41\%. Ez a trend jelzi, hogy a kőzetextraktumok a kerogén típusával összefüggő hatás ellenére jelzik a szénhidrogének termikus érettségét.

Az olajok esetében 1290 N/I adat került értékelésre. A termikusan éretlen és érett állapotot jelzô N/I értékek mélység-intervallumonkénti eloszlása a kőzetextraktumokéihoz hasonló trendet mutat a mélység növekedésével ( $I$. táblázat). Meg kell említeni, hogy az olajok N/I értékeinek eloszlását a kőzetextraktumokéval ellentétben a vertikális migráció is befolyásolja. Ennek tulajdonítható, hogy már kis mélységben (0-2000 m) a termikusan érett fokozatot képviselő magas N/I értékek aránya (29\%) jóval nagyobb, mint a kőzetextraktumok esetében (13\%).

Elég sok biomarker paraméter alkalmas lehet a termikus érettség becslésére annak ellenére, hogy értéküket a kerogén típusa is befolyásolhatja. A biomarkerek közül azt választottam ki, amelyik — amellett, hogy jelzi az érettséget — elegendő számú adattal is rendelkezik. A triaromás C20 és C21 szteránok és az összes triaromás szterán aránya (BTR) százalékban kifejezve az előzőleg említett szempontoknak megfelelt (PeTERs \& MoldowAn 1993). A gáz-kondenzátumokból nem mérhető BTR értékeket a biodegradáció nem befolyásolja, de az organofácies hatással van rá, ezért csak genetikailag egymással összefüggő olajminták esetében alkalmazható (PETERS et al. 2005).

A kőzetextraktumok esetében 570 BTR adat került értékelésre a középső-miocén-pannóniai korú kőzetekből. A 10\%-nál kisebb értékek részaránya a mélység növekedésével csökken, a legalább $70 \%$ értékúeké pedig nô (I. táblázat). Ez a trend arra utal, hogy a BTR-értékek alkalmasak a termikus érettség becslésére.

Az olajoknál 590 BTR adat volt értékelhetô. Az alacsony $(<10 \%)$ és a magas $(\geq 70 \%)$ értékek mélységközönkénti eloszlása a kőzetextraktumokéhoz hasonló trendet mutat (I. táblázat). Érdekes módon az N/I értékektôl eltérôen nincs számottevő különbség a kőzetextraktumok és az olajok eloszlásadatai között ugyanabban a mélységintervallumban. Lehet, hogy ez annak a következménye, hogy az N/I és a BTR adatok nem minden esetben álltak rendelkezésre ugyanazon mintából. Mindenesetre feltûnő, hogy az olajoknál sokkal kevesebb BTR adat volt értékelhetô, mint az N/I adatok esetében.

\section{Az olajok könnyü (benzin) részének termikus érettsége}

Az olajok könnyú részének termikus érettsége megállapítható az ún. izoheptán (IHP) -index segítségével (THOMPSON 1983). Az izoheptán index a 7 szénatomszámú izoalkánok és cikloalkánok aránya, amely a termikus érettség növekedésével nô. Mivel az anyakőzetek könnyú szénhidrogénjeinek analízise még nem vált általános gyakorlattá hazánkban, az IHP-index értékei nem hasonlíthatók össze az anyakőzetekéivel: csak az olaj-olaj korreláció hajtható végre. Gázkondenzátumok esetében csak az IHP-index szolgáltat információt a szénhidrogén-folyadék termikus érettségére vonatkozóan.

1200 IHP adat került értékelésre. A vertikális migrációra

I. táblázat. Az érettségjelző termikus paraméterek eloszlása (\%)

Table I. Distribution of maturity-related thermal parameters (in\%)

\begin{tabular}{|c|c|c|c|c|c|c|c|c|}
\hline \multirow{2}{*}{ Mélység (m) } & \multicolumn{4}{|c|}{ N/l } & \multicolumn{4}{c|}{ BTR } \\
\cline { 2 - 11 } & extraktum & \multicolumn{2}{|c|}{ olaj } & \multicolumn{2}{c|}{ extraktum } & \multicolumn{2}{c|}{ olaj } \\
\cline { 2 - 10 } & $<1$ & $\geq 2$ & $<1$ & $\geq 2$ & $<10$ & $\geq 70$ & $<10$ & $\geq 70$ \\
\hline $0-2000$ & 38 & 13 & 19 & 29 & 43 & 3 & 19 & 1 \\
\hline $2000-2500$ & 25 & 22 & 8 & 53 & 25 & 4 & 14 & 5 \\
\hline $2500-3000$ & 14 & 34 & 5 & 57 & 5 & 21 & 4 & 33 \\
\hline$\geq 3000$ & 7 & 41 & 1 & 80 & 0 & 61 & 3 & 47 \\
\hline
\end{tabular}


utal, hogy a 2000 méternél kisebb mélységben lévő tárolókôzetekben a 2-nél nagyobb, igen érett fokozatnak (THOMPsON 1983) megfeleló IHP-értékek jelentős hányadot (35\%) képviselnek.

\section{A gázok termogén komponenseinek érettsége}

A gázok termogén komponenseinek, az etánnak és a propánnak szénizotóparány-különbsége alkalmas a termikus érettség becslésére (JAMES 1983, 1990). (Az etánra és a propánra való korlátozás oka az, hogy ezek a komponensek még eléggé jól mérhetők, a nagyobb szénatomszámú, szintén termogén eredetúek már kevéssé.) A módszer előnye az itt nem részletezett más módszerekkel szemben, hogy független az anyakôzet szerves anyagának, a kerogénnek típusától. A módszer alkalmazásának alapvetô feltétele az, hogy az etán és a propán ugyanabból az anyakőzetből, ugyanabból a mélységből származzék, azaz kogenetikus legyen. A metán és az etán, illetve a metán és a propán szénizotóparány-különbsége a legtöbb esetben azért nem alkalmazható, mert a metán nem kogenetikus velük: a metán gyakran tartalmaz nem termogén, hanem bakteriális eredetú metánt is (CHUNG et al. 1988). A módszer alapja a már képződött komponensek közötti izotópkicserélődés: minél nagyobb az anyakőzet hőmérséklete, érettsége, annál intenzívebb az izotópkicserélódés, ami a komponensek szénizotóparányában meglévő kezdeti különbséget csökkenti. (A propán izotóposan mindig nehezebb a vele kogenetikus etánnál.) Az etán és a propán szénizotóparánykülönbségéből számítható a termikus érettség vitrinitreflexióegyenértékben (VRE) kifejezve (JAMES 1990). Az ily módon számított vitrinitreflexió annak az anyakőzetnek a termikus érettségét adja meg, amelyből az etán és a propán a primer migráció során távozott. Mivel az anyakőzzetekben lévő, illetve ott maradt etán és propán szénizotóparányai (még) nem ismertek, a VRE-értékek alapján csak azt a mélységet lehet közvetve megadni, amelyből a termogén komponensek származhattak. Ennek viszont az a feltétele, hogy a vizsgált területen rendelkezésre álljon a kôzetek szerves anyagának érettségére jellemző virtinitreflexió-mélység összefüggés.

300 mérési eredményből számított VRE-érték került értékelésre a rétegvizsgálatok gázaiból. A termogén gázok vertikális migrációja jelentôs lehetett, mert 2000 méternél kisebb mélységben az adatok közel felében (48 százalékában) a vitrinitreflexió-egyenérték (VRE) 1,0\% feletti volt, holott a neogén üledékes kôzetek szerves anyagának érettsége ebben a mélységtartományban még az ,olajablak” kezdetére jellemző $0,6 \%$ vitrinitreflexió értéket sem érhette el.

\section{Hazai példák a szénhidrogének feltételezhetô vertikális migrációjára}

\section{Budafa és Lovászi mezók}

Mind a Budafa, mind a Lovászi mező többtelepes elófordulás, amelyben a felhalmozódások a mélyvízi homokkő (,alsó-pannóniai”) tárolókban, 1000-1450 m mélységben vannak. DANK (1988) feltételezte, hogy a Budafa mező olaja az idősebb miocén korú anyakőzetekben keletkezett. A bizonyító erejú olaj-anyakôzet korreláció eredményei szerint a Budafa mezô olajait a középsô-miocén (badeni), a Lovászi mezóéit a mélyebben fekvő alsó-miocén (kárpáti) anyakôzetek hozták létre (KoNCZ 2017). Indokoltan feltételezhetố tehát, hogy az alsó- és középsố-miocén anyakôzetekben képződött szénhidrogének vetôkön keresztül, vertikális migráció révén halmozódtak fel a mélyvízi turbidit rendszerhez, a Szolnoki Formációhoz tartozó homokkőtárolókban. Erre utalnak a Budafa és Lovászi szerkezetek földtani szelvényei (2. ábra) (VÖLGYI et al. 1985). A szelvényeken láthatók a mélyról az említett turbidit rendszerhez tartozó tároló képződményekbe hatoló vetôk.

A Budafa mező szénhidrogénjei termikusan kevésbé érettek, mint a Lovászi mezóéi, ami a generáló anyakőzetek kora és abból következően települési mélységtartománya különbözősége miatt érthetô is: a termikusan érettebb Lovászi olajok a mélyebben fekvő kárpáti anyakőzetek termékei, és vertikális migrációjuk nagyobb mérvú mint a kevésbé érett Budafa olajoké, amelyek a sekélyebben lévő badeni anyakőzetekben képződtek. A Budafa olajok könnyú részének IHP-indexe maximum 0,8 , a Lovászi olajoké 1,0 . A BTR adatokban is hasonló a különbség: a Budafa olajok nehéz részében a BTR maximuma $21 \%$, a Lovászi olajokéban $44 \%$.

Összegezve: Budafa és Lovászi mezők esetében genetikai korrelációval bizonyítottan a sekélyebben fekvő, turbidit rendszerhez tartozó tárolók olajai a nagyobb mélységben lévő idősebb, alsó- és középsô-miocén anyakôzetekből származnak. A tárolók szénhidrogénekkel való feltöltődése minden valószínúség szerint vetôkön keresztül, vertikális migrációval mehetett végbe.

\section{Dráva-medence}

A Dráva-medence Magyarország területére eső északi szárnyán végzett olaj-anyakôzet korrelációk eredményei azt mutatták, hogy az előfordulások szénhidrogénjei a középsômiocén anyakőzetekben keletkeztek (KonCZ et al. 2010). A termikus érettséget jelző geokémiai adatok segítségével megállapítható volt, hogy a kisebb mélységben (1000-2200 m) elhelyezkedô pannóniai tárolóképzódmények szénhidrogénjei termikusan érettebbek, mint a középső-miocén tárolókban (2380, 2520 m) felhalmozódottaké (KoNCZ \& HoRvÁtH 2008). A szénhidrogén-folyadékok geokémiai adatai szerint a deltalebenyeket alkotó, Újfalui Formációkhoz tartozó tárolókban felhalmozódott fluidumok könnyú részében az IHP-indexek 1,7-2,2, a mélyvízi turbidit rendszerhez, a Szolnoki Formációhoz tartozó tárolókéban 1,11,8 és a középső-miocén képződményekben $0,4-0,6$ tartományúak voltak: azaz az elóbbiek érett, az utóbbi éretlen fokozatot képviselt. A szénhidrogén-folyadékok nehéz részében a termikus érettség érdemi különbséget nem mutatott, és az érettség alacsony fokozatú volt. Ebből arra lehet következtetni, hogy a vertikális migráció két lépcsőben mehetett végbe a középső-miocén anyakőzetek túlnyomás 

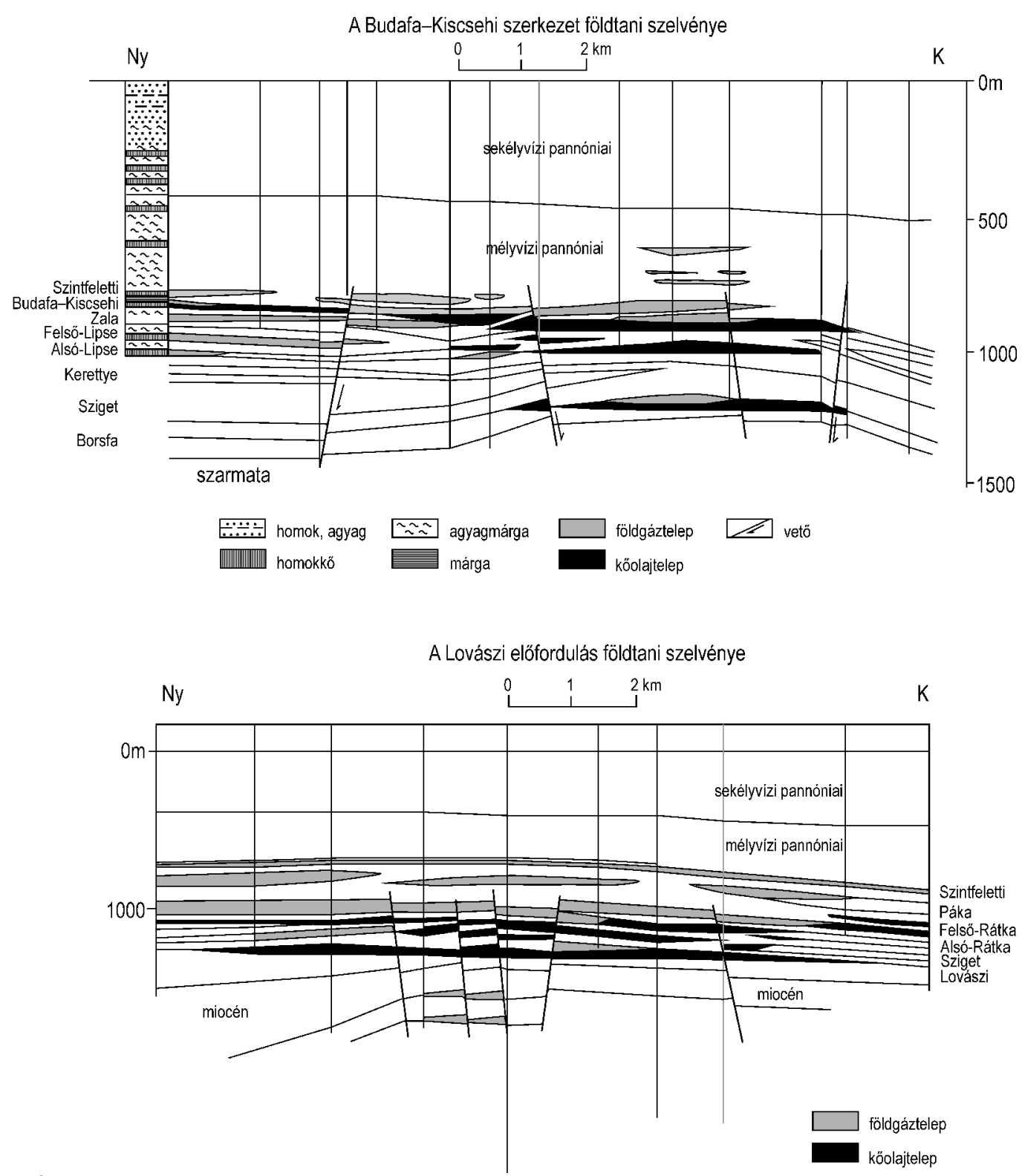

2. ábra. Budafa és Lovászi olajmezők keresztszelvényei (VöLGYI et al. 1985)

Figure 2. Cross sections of Budafa and Lovászi oil fields (VöLGYI et al. 1985)

által okozott ismételt felrepedése miatt. A viszonylag alacsony érettségú nehéz részekkel jellemezhetőket első felrepedés, a pannóniai tároló képzôdmények fluidumait a második felrepedés hozta létre, amely érettebb könnyú résszel rendelkező szénhidrogén-folyadékokat eredményezett.

A mélyebben fekvô részeken a gázok etán és propán szénizotóparány-különbségei alapján becsült vitrinitreflexió egyenérték (VRE) 0,6-0,7\%, viszont ennél kisebb mélységben $1,1 \%$.

A területre jellemző geológiai szelvény rétegtani és tektonikai értelmezéséből kitűnt, hogy a neogén aljzatból kiinduló vetők az Újfalui és Zagyvai Formációkhoz tartozó képződményekig hatoltak, amelyeken keresztül a pannóniai üledékképződéshez rendelt tároló képződmények vertikális migráció révén feltöltődhettek (3. ábra) (KoNCZ \& HoRvÁTH
2008). A geológiai szelvényen a neogén aljzatot fedő középsőmiocén képződmények, köztük anyakőzeteik is, 2000-3000 m tartományban vannak, de a Dráva-medence mélyebb részére, Horvátország területére esik a középső-miocén anyakőzetek fő tömege.

Összegezve megállapítható, hogy a Dráva-medence északi, magyarországi szárnyán a vertikális migrációra két, geokémiai szempontból megalapozott jelenség utal: a sekélyebben fekvő tárolók szénhidrogénjei érettebbek, mint a mélyebben fekvőkéi, továbbá genetikai korrelációkkal bizonyítottan a sekélyebben fekvő tárolók szénhidrogénjei a nagyobb mélységben lévő idősebb, középső-miocén anyakőzetekből származnak. A szemléltetett geológiai szelvényen pedig jól láthatók azok a vertikális migrációs csatornák, vetők, amelyek lehetôvé tették a sekélyebben elhelyezkedő tárolók szénhidrogénekkel való feltöltődését. 


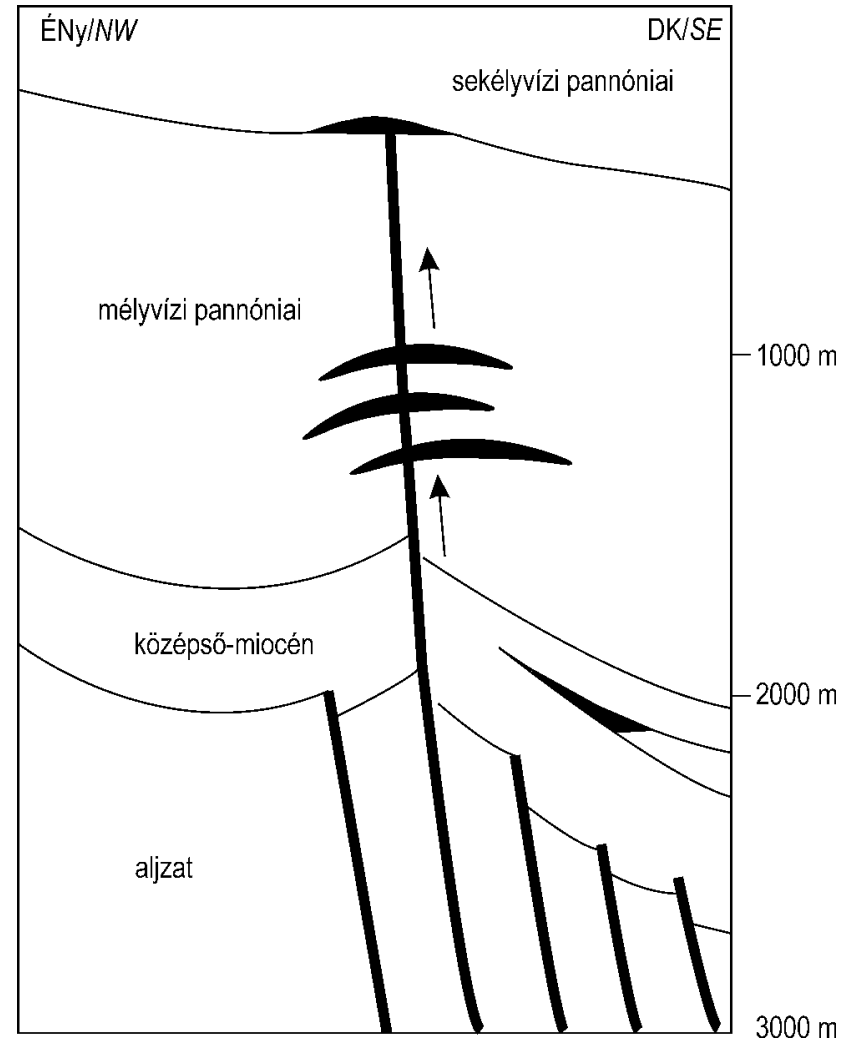

3. ábra. A Görgeteg-Babócsa szerkezet vázlatos keresztszelvénye (KoNCZ \& HORVÁTH 2008)

Figure 3. Schematic cross section of Görgeteg-Babócsa structure (KoNCZ \& HORVÁTH 2008)

\section{Algyó}

Algyőn 69 telep vált ismertté az Újfalui Formációban elhelyezkedő tárolóktól a mélyvízi turbidit rendszerhez (a Szolnoki Formációhoz) tartozókon át a kristályos-metamorf aljzattal összefüggő alapkonglomerátumig. A földtani készletek zöme, 80 százaléka az Újfalui és Zagyvai Formációkban lévő tárolókban helyezkedik el. Az olajok nehéz részében mért eredetjelző biomarkerek azt mutatták, hogy az algyői telepek olajszénhidrogénjei nem származhatnak a szerkezeti magaslattól keletre lévő Makói-árokból (SAJGó 1984). Bizonyítható volt, hogy a kitûnő anyakôzet-tulajdonságokkal rendelkező, Újfalui és Zagyvai Formációkhoz tartozó képződmények sem lehettek a felhalmozódások anyakőzetei (KONCZ \& ETLER 1994). Az olaj-anyakőzet korreláció eredményei szerint a felhalmozódások szénhidrogénjei a középsô-miocén anyakôzetekben képződtek (KoNCZ 2018b). Ennek alapján érthetővé vált, hogy a középső-miocén képződményeket nem tartalmazó Makói-árokból miért nem származhattak az algyői telepek szénhidrogénjei (SzUROMIKorECZ et al. 2004).

Korai felismerés volt, hogy az olajok nehéz részében lévő biomarker-vegyületek érettsége a mélység növekedésével csökken (SAJGó 1984). Az a tapasztalat, hogy a szénhidrogén-folyadékok nehéz részei a legkisebb mélységben a legérettebbek, arra enged következtetni, hogy a kisebb mélységben lévő, Újfalui és Zagyvai Formációkhoz tartozó tárolók szénhidrogénjeit illetően a vertikális migráció a legnagyobb mértékű lehetett. A szénhidrogén-folyadékok könnyú részei azonban egyöntetûen igen érettek: IHP értékeik 2,0 felettiek, és ennek megfelelően igen érett fokozatúak. A nehéz és a könnyú részek érettségében mutatkozó különbségek alapján feltételezhető, hogy a telepek feltöltôdése legalább két lépcsőben mehetett végbe (KoNCZ 2018b). Az elsô lépcső a középső-miocén anyakőzetek első felrepedéséhez köthető, amelyet a túlnyomás megfelelő mértéke idézhetett elő (KoNCZ 2018a). Ebben a stádiumban a kevésbé érett szénhidrogének kerültek vertikális migráció révén a felhalmozódási övezet mélyebben fekvő tárolóiba. A második felrepedés nagyobb mélységben következhetett be, és jóval érettebb és könnyebb szénhidrogéneket továbbíthatott a megnövekedett hosszúságú vető révén a sekélyebben lévő tárolókba is. A telepek gázaiban lévô etán és propán szénizotóparány-különbségei alapján becsült érettség $0,8-$ $1,1 \%$ vitrinitreflexiónak felel meg. A vitrinitreflexió-mélység összefüggések felhasználásával becsülhető volt az a mélységtartomány, amelyben a gázkomponensek képződtek. A becslés 3500-4500 m tartományt valószínúsített. Az előzőek alapján nagymérvű vertikális migrációt kell feltételezni: a mélyen fekvő középső-miocén anyakőzetekben képződött szénhidrogéneket az Újfalui és Zagyvai Formációkban elhelyezkedô tárolókig vezethette olyan, a neogén aljzatból kiinduló vető, amelyet a 4. ábra szemléltet (KóKAI \& PoGÁcsÁs 1991).

Az algyôi szerkezet telepeinek szénhidrogénjei a vertikális migráció mindhárom jellemzőjét képviselik. A sekélyebben fekvő és az Újfalui-Zagyvai Formációkhoz tartozó tárolók olajainak nehéz része jóval érettebb, mint a mélyebben fekvőké. Genetikai korrelációkkal bizonyítottan a sekélyebben fekvő tárolók szénhidrogénjei a nagyobb mélységben lévő középsố-miocén anyakőzetekből származnak. A készletek zömét magában foglaló és az ÚjfaluiZagyvai Formációkhoz tartozó tároló képződmények termikusan igen érett szénhidrogéneket tartalmaznak, viszont a

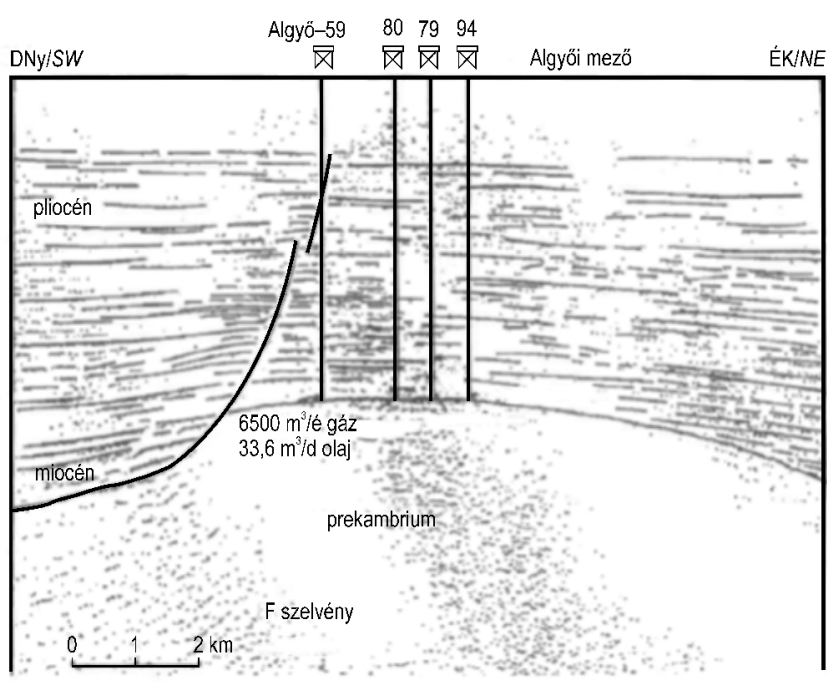

4. ábra. Az algyői szerkezet interpretált szeizmikus szelvénye (KóKAI \& PogÁCSÁs 1991)

Figure 4. Interpreted seismic section of Algyö structure (KóKAI \& POGÁCSÁS 1991) 
telepek környezetében lévő kőzetek szerves anyaga éretlen, legfeljebb a $0,5 \%$ vitrinitreflexiónak megfelelő értettséget érte el (HETÉNYI et al. 1993).

\section{Derecskei-süllyedék}

Az Újfalui-Zagyvai Formációkhoz tartozó képződmények tárolókőzeteiben gáz-gázkondenzátum telepeket tártak fel. Az etán és propán szénizotóparány-különbségéből számított vitrinitreflexió egyenérték 1,2\%. Ezt az érettséget a $3100 \mathrm{~m}$ mélységben lévő, mélyvízi turbidit rendszerhez tartozó képződmények érték el. A felhalmozódások környezetében az érettség nem éri el a 0,6\% vitrinitreflexiónak megfelelőt. Tehát jelentős mérvú vertikális migráció révén halmozódhatott fel a 3000 méternél mélyebben képződött gáz az Újfalui-Zagyvai Formációkhoz tartozó tárolókőzetekben. A földtani szelvényen egy vetôzóna látszik, amelyen keresztül a vertikális migráció végbemehetett (5. ábra) (BALÁzs et al. 2016).

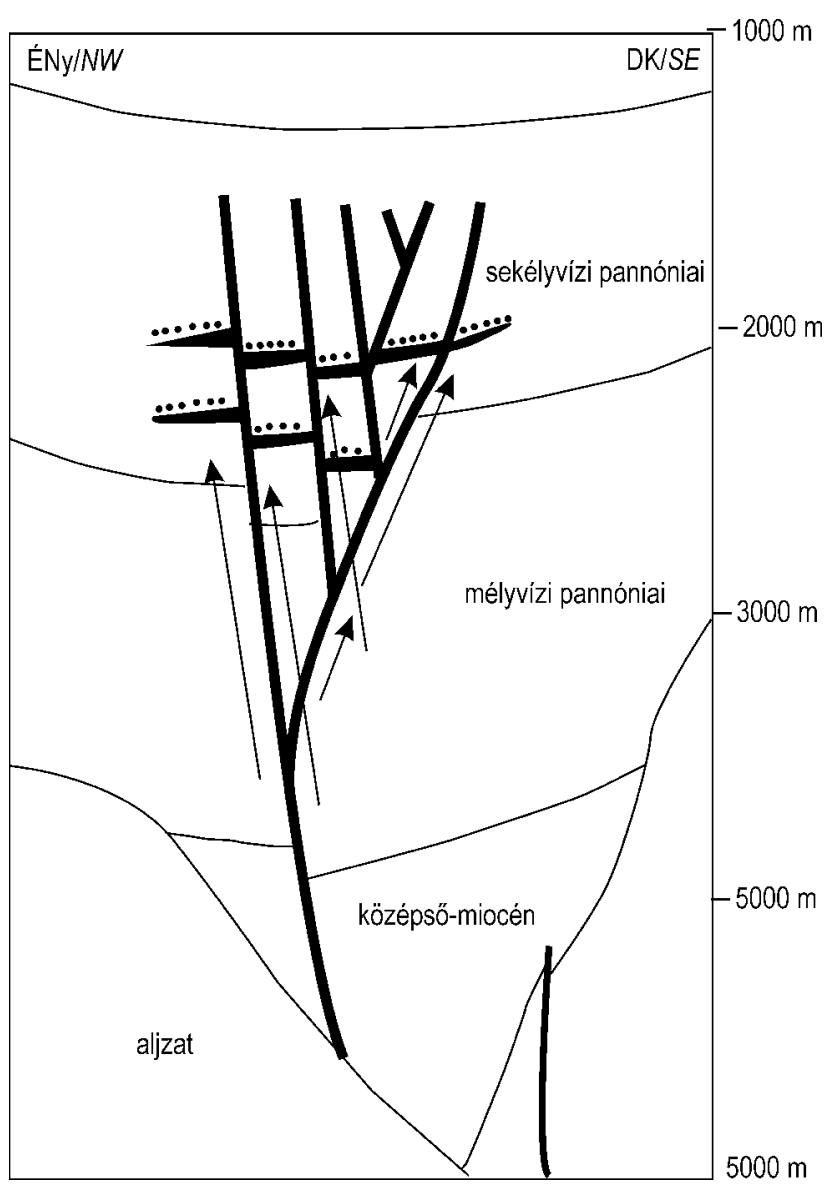

5. ábra. A Derecskei-süllyedék vázlatos keresztszelvénye (BALÁzs et al. 2016) Figure 5. Schematic cross section of Derecske depression (BALAZSS et al. 2016)

\section{Hajdúszoboszló}

A Hajdúszoboszlón felfedezett többtelepes gáz-előfordulás 450-1260 m mélységtartományban helyezkedik el. A tárolókőzetek kora a mezozoos (felsô-kréta) flistől a felső-pliocén összletig terjed. Vetőket nem mutattak ki. A metán szénizotóparánya és a gázok C2+ tartalma a mélység növekedésével jellegzetes trendet mutat: a metán izotóposan nehezebbé válik, és a $\mathrm{C} 2+$ tartalom nő (6. ábra). $\mathrm{Az}$ említett trend a termogén eredetû gázok vertikális migrációjának tulajdonítható (KoNCZ, megjelenés alatt). A vertikális migráció ez esetben valószínúleg nem vetôkön keresztül ment végbe, hanem a vízben oldott állapotú termogén gázok migrálhattak a kisebb nyomású, sekélyebben elhelyezkedő tárolókba a még nem eléggé tömörödött, laza zárórétegeken át. A felvázolt kép a bakteriális eredetû gáz és az alulról felfelé szivárgó termogén gáz elegyedésének következtében állhatott elő. (A bakteriális eredetű metán alacsony koncentrációjú lehetett a vízben, és csak azért tudott gázfázist képezni, mert a termogén metán megnövelte a víz gáztartalmát egészen addig, amíg a helybeni viszonyoknak megfelelő vízben való oldhatóságot elérte, illetve meghaladta.)

Egy hajdúszoboszlói fúrásban, 800-1800 m mélység-

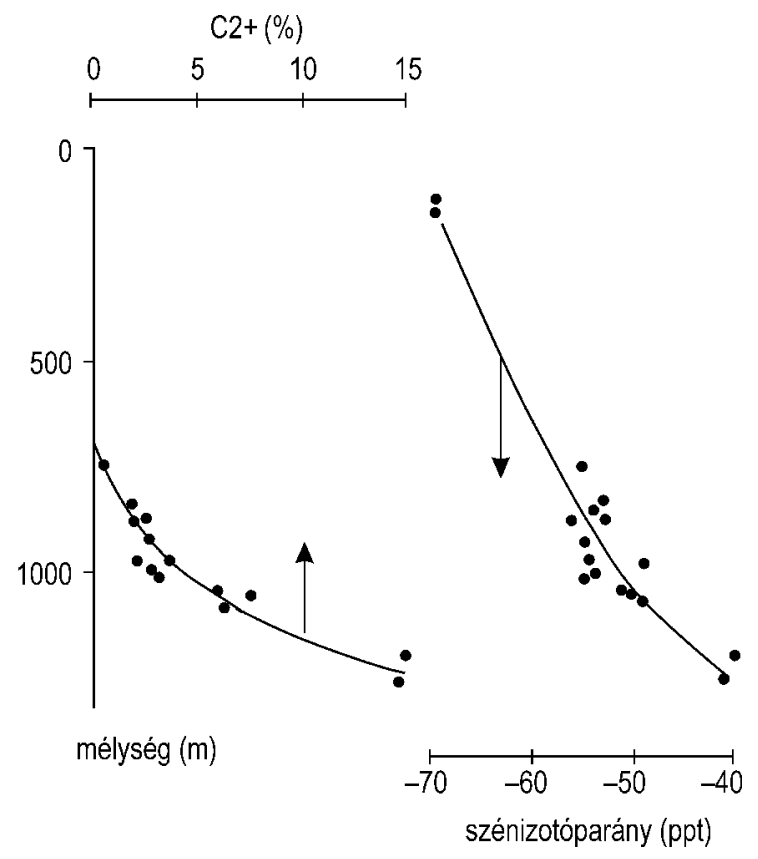

6. ábra. A Hajdúszoboszló gáz mező szénizotóparány és $\mathrm{C} 2+$ trendjei Figure 6. Stable Carbon Isotope Ratio and C2+ trends of Hajdúszoboszló gas field

intervallumban az etán és a propán szénizotóparány-különbségéből számított vitrinitreflexió egyenérték elég magas, 1,1-1,2\% volt, ami a jelzett mélységhez képest igen érettnek tekinthetô. Lehetséges, hogy a hajdúszoboszlói gáztelepek termogén komponensei a neogén aljzatot képzô flisből származnak.

\section{Diszkusszió}

A szénhidrogén-felhalmozódásoknak a vertikális migráció révén végbemehetett képződése viszonylag korán felvetôdött (PRICE 1980). Ennek ellenére a geokémiai para- 
méterek, valamint a genetikai korrelációk eredményeinek felhasználása a vertikális migráció valószínúsítésére nem vált általánossá.

Az előzőekben részletezett példák szerint a fliszóna felső-kréta-paleogén korú képződményeinek (Hajdúszoboszló), a középső-miocén anyakôzzeteknek (Budafa és Lovászi mezők, Dráva-medence, Algyő) és az idősebb pannóniai korú anyakőzzeteknek (Derecskei-süllyedék) a szénhidrogénjei képeztek felhalmozódásokat a pannóniai képződmények tárolókőzeteiben. Ezek a felhalmozódások rétegmenti (laterális) migráció révén nem jöhettek létre. A felhalmozódások környezetében lévő kőzetek szerves anyagánál a telepek szénhidrogénjei termikusan jóval érettebbek.

\section{Következtetések}

Az előzőekben részletezett példák arra utalnak, hogy a pannóniai képződményekhez tartozó tárolókőzetekben olyan szénhidrogén-felhalmozódások vannak, amelyek vertikális migráció révén jöhettek létre. A vertikális migráció az esetek többségében vetôkön keresztül mehetett végbe. A vetốk egy része a neogén aljzati képződményekből indulóan a sekélyebben elhelyezkedő tároló képződményekig hatolt, és feltehetően tektonikus eredetú. A másik részük valószínúleg a középsô-miocén üledékes kőzetekbôl indult a kôzetek túlnyomás által okozott felrepedése, ezt követô térfogatcsökkenése következményeként, és - esetleg több, időben elkülönüló fokozatban - elérte a sekély tárolókat. A vetők hiányában is megvalósulhatott a vertikális migráció Hajdúszoboszló esetében.

\section{Irodalom — References}

Balázs, A., Matenko, L., Horváth, F. \& Cloething, S. 2016: The link between tectonics and sedimentation in back-arc basins: New genetic constrains from the analysis of the Pannonian Basin. — Tectonics 35/6, 1526-1559. https://doi.org/10.1002/2015tc004109

Bostick, N. H. 1979: Microscopic measurements of catagenesis of solid organic matter in sedimentary rocks to aid exploration for petroleum to determine former basin temperatures — a review. — In: Scholle, P. A. \& SchlugER, P. R. (eds): Aspects of diagenesis: Society of Economic Paleontologists and Mineralogists Special Publication 26, 17-43. https://doi.org/10.2110/pec.79.26.0017

Brooks, J., Cornford, C. \& ARCHER, R. 1987: The role of hydrocarbon source rocks in petroleum exploration. - Marine Petroleum Source Rocks, Geological Society Special Publication 26, 17-46. https://doi.org/10.1144/gsl.sp.1987.026.01.02

Chung, H. M., Gormly, J. R. \& SQuires, R. M. 1988: Origin of gaseous hydrocarbon in subsurface environments: Theoretical consideration of carbon isotope distribution. — Chemical Geology 71, 97-103. https://doi.org/10.1016/0009-2541(88)90108-8

Connan, J. 1974: Time-temperature relation in oil genesis: geological notes. — AAPG Bulletin 58/12, 2516-2521. https://doi.org/ 10.1306/83d91beb-16c7-11d7-8645000102c1865d

Cosgrove, J. W. 2001: Hydraulic fracturing during formation and deformation of a basin: A factor in the dewatering of low-permeability sediments. - AAPG Bulletin 85/7, 737-748. https://doi.org/10.1306/8626c997-173b-11d7-8645000102c1865d

DANK, V. 1988: Petroleum Geology of the Pannonian basin, Hungary: An overview. — In: The Pannonian basin: A study in basin evolution, AAPG Memoir 45, 319-331.

Demaison, G. \& Huizinga, B. J. 1994: Genetic Classification of Petroleum Systems Using Three factors: Charge, Migration, and Entrapment. — In: Magoon, L. B. \& Dow, W. G. (eds): The Petroleum System — From Source to Trap. AAPG Memoir 60, $73-89$.

DownEY, M. W.1984: Evaluating seals for hydrocarbon accumulation. — AAPG Bulletin 68, 1752-1763. https://doi.org/10.1306/ ad461994-16f7-11d7-8645000102c1865d

Downey, M. W. 1994: Hydrocarbon Seal Rocks. — In: MAGoon, L. B. \& Dow, W. G. (eds): The Petroleum System — From Source to Trap. AAPG Memoir 60, 159-164.

DURAND, B. 1988: Understanding of HC migration in sedimentary basins (present state of knowledge). _ Organic Geochemistry 13/13, 445-459. https://doi.org/10.1016/b978-0-08-037236-5.50052-x

HetÉnYi, M., KonCZ, I. \& SZALAY, Á. 1993: Organic geochemical evaluation of the Makó-3 borehole. — Acta Geologica Hungarica 36/2, 211-222.

Hobson, G. D. 1954: Some fundamentals of Petroleum Geology. - Oxford University Press, London - New York - Toronto. https://doi.org/10.1017/s001675680006653x

Hunt, J. M. \& JAMIESON, G. W. 1956: Oil and organic matter in source rocks of petroleum. — AAPG Bulletin 40, $477-488$. https://doi.org/10.1306/5ceae3e8-16bb-11d7-8645000102c1865d

HunT, J. M. 1990: Generation and Migration of Petroleum from Abnormally Pressured Fluid Compartments. — AAPG Bulletin 74/1, 112. https://doi.org/10.1306/0c9b21eb-1710-11d7-8645000102c1865d

JAMES, A. T. 1983: Correlation of Natural Gas by Use of Carbon Isotopic Distribution Between Hydrocarbon Components. - AAPG Bulletin 67/7, 1176-1191. https://doi.org/10.1306/03b5b722-16d1-11d7-8645000102c1865d

JAMES, A. T. 1990: Correlation of Reservoired Gas Using the Carbon Isotopic Compositions of Wet Gas Components. - AAPG Bulletin 74/9, 1441-1458. https://doi.org/10.1306/0c9b24f7-1710-11d7-8645000102c1865d

KóKAI, J. \& PoGÁCSÁs, Gy. 1991: Hydrocarbon plays in Mesozoic nappes, Tertiary wrench basins and interior sags in the Pannonian basin. - First Break 9/7, 315-334. 
KoncZ, I. \& EtLER, O. 1994: Origin of oil and gas occurrences in the Pliocene sediments of the Pannonian basin, Hungary. - Organic Geochemistry 21/10-11, 1069-1080. https://doi.org/10.1016/0146-6380(94)90070-1

KonCZ, I. \& HoRváth, Zs. 2008: Probable migration mechanisms of hydrocarbons in Drava Basin. — 27th International Petroleum \& Gas Conference and Exhibition, Siófok, Abstracts, PO1

Koncz I., LukÁcs T., Horváth Zs., Gellért B., KajáRi M., Cota L., Balen M. \& BigunaC D. 2010: Az alsópannon és középsőmiocén anyakőzetek organikus fáciese a Dráva-medence északi szárnyán. - Medencefejlódés és geológiai erőforrások: víz, szénhidrogén, geotermikus energia; a Magyarhoni Földtani Társulat vándorgyúlése, Szeged, GeoLitera 121-122.

Koncz I. 2017: Budafa és Lovászi mezők olajának származása. — Bányászati és Kohászati Lapok, Bányászat - Köolaj és Földgáz 150/5, 6-9.

Koncz I. 2018a: A túlnyomás szerepe szénhidrogén-telepeink létrejöttében. — Bányászati és Kohászati Lapok, Bányászat - Köolaj és Földgáz 151/1-2, 6-10.

Koncz I. 2018b: Az algyői telepek szénhidrogénjeinek eredete és migrációs modellje. — Bányászati és Kohászati Lapok, Bányászat — Köolaj és Földgáz, 151/5-6, 17-23.

Koncz I.: Bakteriális eredetû metánt tartalmazó földgáztelepeink. — Bányászati és Kohászati Lapok, Bányászat — Köolaj és Földgáz, (megjelenés alatt)

Nelson, P. H. 2009: Pore-throat sizes in sandstones, tight sandstones, and shales. — AAPG Bulletin 93/3, 329-340. https://doi.org/ $10.1306 / 10240808059$

Payne, D. F., Tuncay, K., Park, A., Comer, J. B. \& Ortoleva, P. J. 2000: A Reaction-Transport-Mechanical Approach to Modeling the Interrelationships Among Gas Generation, Overpressuring, and Fracturing: Implications for the Upper Cretaceous Natural Gas Reservoirs of the Piceance Basin, Colorado. - AAPG Bulletin 84/4, 545-565. https://doi.org/10.1306/c9ebce4b-1735-11d7$8645000102 \mathrm{c} 1865 \mathrm{~d}$

Peters, K. E. \& Moldowan, J. M. 1993: The Biomarker Guide. 247 p.

Peters, K. E., Walters, C. C. \& Moldowan, J. M. 2005: The Biomarker Guide. - Cambridge University Press, I-II, 1155 p. https://doi.org/10.1017/cbo9781107326040.012

PRICE, L. C. 1980: Utilization of vertical oil migration in deep basins. - Journal of Petroleum Geology 2/4, 353-387. https://doi.org/ 10.1306/bf9ab5b7-0eb6-11d7-8643000102c1865d

RoNov, A. B. 1958: Organic carbon in sedimentary rocks (in relation to the presence of petroleum). — Geochemistry 5, 497-509.

Rouchet, J. 1981: Stress Fields, a Key to Oil Migration. — AAPG Bulletin 65/1, 74-85. https://doi.org/10.1306/2f919774-16ce-11d7$8645000102 \mathrm{c} 1865 \mathrm{~d}$

SAJGÓ, Cs. 1984: Organic geochemistry of crude oils from Southeast Hungary. — Organic Geochemistry 6, 560-578. https://doi.org/ 10.1016/0146-6380(84)90079-2

Shanley, K. W., ClufF, R. M. \& Robinson, J. W. 2004: Factors controlling prolific gas production from low-permeability sandstone reservoirs: Implication for resource assessment, prospect development, and risk analysis. — AAPG Bulletin 88/8, 1083-1121. https://doi.org/10.1306/03250403051

Sorkhabi, R., Tsuji, Y. 2005: The Place of Faults in Petroleum Traps. — In: SorkhaBi, R. \& TsuJI, Y. (eds): Faults, fluid flow, and petroleum traps. - AAPG Memoir 84, 1-31.

Stahl, W., FAber, E., CAReY, B. D \& KirKSEG, D. L. 1981: Near-Surface Evidence of Migration of Natural Gas from Deep Reservoirs and Source Rocks. — AAPG Bulletin 65, 1543-1550. https://doi.org/10.1306/03b59611-16d1-11d7-8645000102c1865d

SzALAY Á. \& KonCZ I. 1980: Szénhidrogén-képződési és migrációs folyamatok a délkeletalföldi és a Dráva süllyedékekben. —Köolaj és Földgáz 13 (113)/6, 177-186.

SZALAY Á. 1982: A rekonstrukciós szemléletű földtani kutatás lehetőségei a szénhidrogén-perspektívák előrejelzésében a DK-Alföldi neogén süllyedékek területén. - Kézirat, kandidátusi értekezés.

Szuromi-Korecz, A., SüTő-SzentaI, M. \& Magyar, I. 2004: Biostratigraphic revision of the Hod-I well: Hungary's deepest borehole failed to reach the base of the upper Miocene Pannonian Stage. - Geologica Carpathica 55, 475-485.

Thompson, K. F. M. 1983: Classification and thermal history of petroleum based on light hydrocarbons. — Geochimica Cosmochimica Acta 47/2, 303-316. https://doi.org/10.1016/0016-7037(83)90143-6

Tissot, B-P. \& Welte, D. H. 1984: Petroleum Formation and Occurrence. — Springer-Verlag, 185 p. https://doi.org/10.1007/978-3-64287813-8

Völgyi L., Szerecz F., Hajdú D., Kurucz B., MésZÁRos L., NéMETh G., FöldeÁK P.-NÉ, SzentGyörgyi K.-NÉ, Horváth R., Kovács Zs., TormÁssyné VARGa É., Dallos E.-NÉ, NAGY M.-NÉ, \& SzỨcs L. 1985: Magyarország kóolaj-és földgáz-elófordulásai (1935-1985).

Kézirat beérkezett: 2019. 03. 21. 